Journal of Business and Tourism

Volume 06 Number 01

January - June, 2020

\title{
The Impact of Work Life Balance, Role Conflict and Work Overload on Employee Turnover Intention through the mediating role of Job Stress
}

\author{
Syed Majid Khalil \\ Ph.D. Scholar, Islamia College Peshawar, Pakistan \\ Sher Nawaz Khan \\ Lecturer, Department of Tourism, Abdul Wali Khan University Mardan, Pakistan \\ Dr. Fayaz Ali Shah \\ Assistant Professor, Islamia College Peshawar, Pakistan
}

\begin{abstract}
The current study is to find out the impact of Work Life balance, Role Conflict and Work Overload on Employees Turnover Intention with the mediating role of job stress of Abdul Wali Khan University (AWKUM) of Khyber Pakhtunkhwa. Working in educational institutions is complex and dynamic in nature, therefore in these conditions employees faces many stresses. Referable to the most troubling of these fears the most affected relationship is the low performance of employees working in Abdul Wali Khan University (AWKUM) because of the stress. Different stressor in the management of universities like Work Life Balance, Role conflict and Work Overload are important determinants of stress. The workplace has some harsh realities, worldwide one of the basic challenges facing in an organization is their employee's performance affected by stress. The employees who are working in different sectors of an organization have to deal with stress. Similarly, the university workers are among the same to deal with the stress. The performance of an organization is dependent on employee's working ability and if the employees are in stress than their overall performance will be negatively affected, resulting in inefficiency and staff turnover. . To study stress in universities, the survey has conducted through a questionnaire designed by the Donald A Buckingham (2004) and KavithaVenugobal (2017). The questionnaire was sent to 300 respondents and 270 answered the questionnaire, which represents a response rate of $89.6 \%$. Based on data collected, the correlation and regression of the variables were carried out in SPSS. The outcomes of the analysis show that Work Life Balance negatively affects the stress level of employees while Role Conflict and Work overload positively affect the job stress level of employees. As the job stress is the mediator in the study, its effect on employee turnover intention is positive. This study will help decision-makers to identify important stresses and see their impact on job stress.
\end{abstract}

Keywords: Job Stress, Work Life Balance, Role Conflict, Work Overload and Employees Turnover Intentions. 


\section{Introduction}

Life becomes busy and people at work face many challenges thus resulting in stress. Stress is a mental and physical reaction that becomes a part of people's daily life. People who are working in different organizations have to deal with different types of pressures and one of the common pressure at the workplace is work stress. In recent years, the employee of the university sectorfaces much stress due to much higher turnover intentions. On the other hand, the organization needs to retain their employees to minimize the turnover intention. Turnover intention describesthe employee's frequency of leaving the organization and that affect the rating and sustainability of the organization. Employee turnover intention is the process in which the staff wants to leave the organization for some reasons. An employee who is working in tough routine of an organization gradually their intention will start to develop to quit the job in the near future (Long \&Thean, 2011).

There are many literatures and researchers have done research on stress. Work-related stress and work overload stress is found from the study of Sheraz et al. (2014).Mostly the stress at work arises on an employee due to heavy work overload, job insecurity, social relationships in the workplace and role conflict.

The paper aims to review the influence of job stress on employee's turnover intention. Thus, this paper developed a conceptual framework that explains the influence of job stress on employee's turnover intention.

\section{Review of Literature}

\section{Job Stress}

There are many theories on stress by researchers with different frameworks. However, these theories have one common characteristics stress. Stress has a direct relationship to the organization; mostly it occurs due to high demand of work as the higher management has expectations from their employee. The management assign multi task to an employeeand expect for positive result with tight deadlines. This leads to stress factor on an employee because sometime his knowledge and ability becomes a challenge to deal with the task.

One of the pioneer of stress researcher is Hans selye. (1955), who develop research on stress. According to him working in tough condition of organization, it is good for the employee he or she learn more and in such circumstances it leads to take decision that is more accurate.

Usually the job stress happens when the demand and capabilities of an employee does not meet (Blaug, 2007). Salami (2011), mentioned job stress is the skills of negative emotions that includes anger, tension, and frustration these are the results, which the employee faces inthemselves. The performance is the capability of the employee to work competently so that the goals of the organization should be achieved (Kovach, 1987).

The employee's performancefor the organization is a prime concern. Employers want their employees to producebest results for the organization, so that the organization can 
compete in the market with their competitors. In universities, expectations of students have raised up the level of working demands and outward stress among employees of universities. In an educational sector, stress is a serious challenge for both staff and faculty. Thus, this study will examine the impact of work life balance, role conflict and work overload on employee turnover intention with mediating role of Job Stress.

\section{Work Life Balance}

Every organization has set workinghours. Employee prefer to work as per schedule but it become unacceptable when the management demands the employee to work after working hours (Karatepe, 2008; Karatepe\&Aleshinloye, 2009; Mansour, 2012). It also start affecting the work and family life just because of stressful working conditions (Namasivayam\& Zhao, 2007; Yavas, Babakus, \&Karatepe, 2008)

The researchers are working on work life balance from past numerousyears (Greenhaus\& Powell, 2006); because of work life balance, it has a negative effect on both the individual and organization. Earlier studies has shown that the work life balance is affecting the stress at work which leads tolow performance and employees find themself in a situation where they wants to switch the job (Armour, 2002; Karatepe, 2010; Karatepe\&Baddar, 2006; Karatepe\&Sokmen, 2006; Namasivayam\& Mount, 2004; Namasivayam\& Zhao, 2007).

Kinman (2014); has given his opinion that over the last 20 years the working condition of academia has changed as there are more students enrolled and the workload increased. The teacher's quality of work hasreformed, as they have to teach and conduct research as well. Similarly, the staff in educational institute also reformed, as they have to work extra without overtime (Statistical Bulletin, 2013).

After manystudies, scholars are now contributing in implementing new organizational policies that may not disturb the work and family life. The effect of work pressure and family life balance is still uncertain (Chiang et al., 2010). Studies have surprisingly shown that these policies are decreasing work life balance (Frone, 2003).

\section{Role Conflict}

When an incompatible demand related to an employee job or position is placed, it results in role conflict. In recenttime, if the organization have to stay in the business with their competitor they have to perform well. Due to which an employeeface several expectations from both themselves and employers.It becomes hard for employees to maintain their efficiency. This in turn results in several mismatched expectations,turn to role conflict and that leads to lower job satisfaction of an employee (Kahn, Wolfe, Quinn et al, 1964).Role conflict can also be defined as that "A different behavioural tasks that have given to single person for positive output that leads to conflict" (Rizzo, House, \&Lirtzman, 1970, p155).

Role theory, conflict(e.g., House, Schuler \&Levanoni, 1983; Rizzo et al., 1970) specifies that it leads to extensive negative impact on the employee who had been experiencing it. They become unhappy with the working conditions and the devoted feelings fades from 
their existing job (e.g., Jackson \& Schuler, 1985; Jawharlal, Stone, \&Kisamor, 2007; Tubre\& Collins, 2000)

Jones (1993) has stated some positive aspects of role conflict is like a regular battle with a conflicting role to make the employee more flexible, open or expand to gain more source of information in their field of work. From those consequences employee has developed more skills to adjust themselves with conflict of roles. In some cases, thoseconflicts of role have made some positive resolution as well in form of teamwork and become cooperative among different employee or groups.During the service when the employee received an unpredictable expectation and that expectation blocked the success of expectation. Role conflict mentioned as a variation which interrupts the performance of a task (Rizzo, House, \&Lirtzman, 1970). Role conflict and turnover intention is positive Chen et al. (2011) as mentioned in his study while Sheraz et al. (2014) identified that there is positive effect of role conflict on stress.

\section{Work Overload}

Work overload means to achieve more work in less time (Claessens, Eerde, Rutte, \& Roe, 2004). A study has taken place in the United Kingdom to find out the behaviour towards their current job. The study shows that the work overload affects the employee working hours, which makes them uncomfortable with their current job, to meet the target the workers needs more time to achieve the target or deadlines.

Several effects occur due to work overload. One of the effect of work overload is the conflict between work and family (Britt, \& Dawson, 2005). The work overload works as a connector between real work requests and to achieve the demands(Bliese, \& Castro, 2000). Once the worker has been through they realize that the task handed over to them are much bigger than their capacity, at that point the work stress intends the workers to start thinking to turn over intention (Hon, Chan, \& Lu, 2013). The real threat to the organization is work overload because if the employee is not satisfied with the work environment and has loaded task to achieve in less time the productivity of the organization may not be completed on time (Duxbury, \& Higgins, 2001).

The organizational management effects due to the stress factor, it leads the work overload, and turnover intention to indirect relationship than the job satisfaction become job stress, which in turn leads to turnover intentions. There is a null relationship between work overload and employee turnover intention, which can be seen in previous research of Tinker, \& Moore, 2001.The employee's health canaffected by stress and the indirect cause of turnover intentions. (Firth, Mellor, Moore, \&Loquet, 2004). Mostly work overload happens when an employeehas observed that the demands are gradually increasing and surpass to their abilities of inspiration to achieve positively the task (Singh 1998).

The past researches show the positive relationship and this paper will also reflect that work overload and turnover intention has positive relationship. 


\section{Employee Turnover Intention}

Sometime during employee's career it happens that the employee due to certain reasons has to decide whether to continue the existing job with the organization or to quit Oluwafemi (2013). Similarly, Long et al. (2016); Tuzun (2007) also defined turnover intention of employee who will leave the organization either in his best interest to gofor a better job or the employee has estimated that the period of time spent with the organization was well enough.

The turnover intention is an important issue, and it is a serious matter for all organizations to pay attention to such phenomena. For an organization, it is important to choose the staff with right competence for their organization's success (Ahmed \& Nawaz, 2015).

Phetkaew (2015) said nowadays employee turnover is a nightmare for many organizations because when an employee leaves the organization is badly affected as they have to recruit a new employee as well as train them, it mayaffect the work continuity. The author concludes that it is a serious challenge for an organization when a high performing employee leave the organization, especially at that time when it is hard for the organization to find a replacement for that particular position.

Nyamubarwa (2013) is keen to investigate turnover intention of employees and take a proper timely action instead once the employee leaves the organization and higher management than start addressing. Once the employee leave the organization, the employer can do nothing but to bear the cost of appointing new staff and train him again. An employeeleaves an organization due to several reasons and one could be less remuneration employee turnover is expensive for an organization. It is an additional burden when an employee leaves the organization and the organization have to bear the turnover of employees (Mbah\&Ikemefuna, 2012).

\section{Statement of the problem}

The current study will examine the relationship of Work Life Balance, Role conflict and Work overload on the employee's turnover intentions of AWKUM. The aim of our study to investigate the given sub objectives.

- To find the effect of Work Life Balance on Job Stress.

- To find the effect of Role Conflict on Job Stress.

- To investigate the effect of Work Overload on Job Stress.

- To see the Impact of Job Stress on Employees' Turnover Intention in AWKUM.

- To examine the nature of job stress faced by AWKUM employees. 


\section{Theoretical Framework}

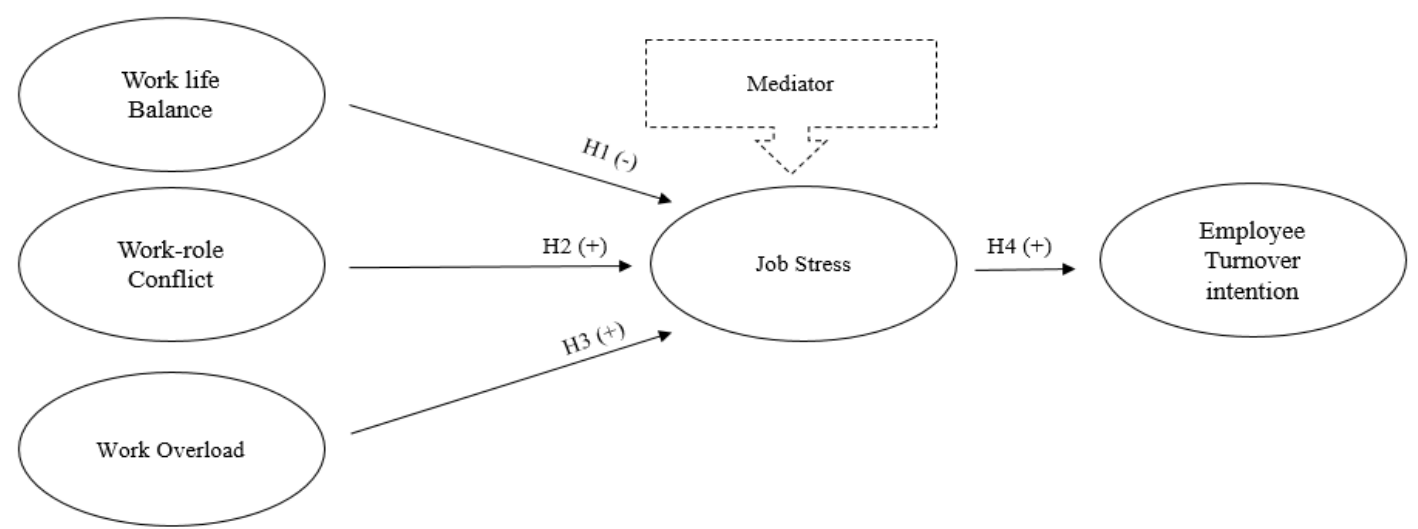

\section{Research Hypothesis}

The paper carries following hypothesis:

- $\quad \mathrm{H} 1$ =Work Life Balance has a negative relationship with Job Stress.

- $\quad \mathrm{H} 2=$ A Positive relation between Role Conflict and Job Stress.

- $\mathrm{H} 3=$ A positive relation between Work Overload and Job Stress.

- $\mathrm{H} 4=$ Job Stress has positive impact onEmployee Turnover Intentions.

\section{Population and Sampling}

\section{Research Methodology}

This study will check the job stress as a mediator along with the determinants including Work Life balance, Role Conflict and Work Overload on Employees Turnover Intentions. The study took place at the Abdul Wali Khan University (AWKUM) of Khyber Pakhtunkhwa. Respondents included employees of BPS 11 to BPS 21. The population of the study was 820 .

The size of the sample for this study, which included employees from grade 11 to 21(Ministerial Staff, Officers and Faculty members)of Abdul Wali Khan University, Mardan (AWKUM).The sample size of 269 was derived from Yamane's formula as mentioned below;

$$
\mathrm{n}=\frac{\mathrm{N}}{1+\mathrm{N}(\mathrm{e})^{2}}
$$


Where:

$$
\begin{aligned}
& \mathrm{n}=\text { indicates the Sample Size } \\
& \mathrm{N}=\text { indicates the Population } \\
& \mathrm{e}=\text { indicates the Error Margin }(5 \%)
\end{aligned}
$$

\section{Instrumentation}

A survey was conducted to gather the information through primary data collectionmethod. The questionnaire included six sections, the first section is on demographic aspects, second section starts with the job stress that the employee owns which is measured with the help of 4 items, work overload which is in the third section and is consistedof 4 items. The fourth section had covered the role conflict with a total of 04 items, the fifth section related to work life balance with 5 items and the last one is of employee's turnover intention with the same 5 items. "Likert Scale" has used to measure the independent and dependent relationship of variables. Statistical instruments such as regression and correlation and other related tests were used to find dependent and independent variables affiliation.

\section{Data Collection}

The data been collected through a questionnaire. The university was visited and employees were requested to fill the questionnaires. Approximately 300 questionnaires were circulated in each section and department of the university in order to get the response of employees.

\section{Data Analysis}

In this study when the data collected, SPSS software was used for quantitative analysis. Demographic analysis, Reliability of the construct, test, Correlation analysis and Regression analysis test took place and are presented in the tables below.

\section{Demographical Analysis}

Demographic characteristics revealed that in 270 respondents, the male respondents were 66.7 percent, whereasfemale respondents were 33.3 percent. Qualification of respondentswas recorded with a maximum of 59.3 percent with postgraduate degree and 2.2 percent with intermediate and below respondents. Upon analyzing the current position of the respondents it has been observed that 44.1 percent employees were in BPS 18 and 19 whereas 5.2 percent employees were in BPS 20 and 21. 
Table: 1

Gender

\begin{tabular}{llrrrr}
\hline & & & \multicolumn{2}{c}{ Valid } & Cumulative \\
& & Frequency & Percent & Percent & Percent \\
\hline Valid & Male & 180 & 66.7 & 66.7 & 66.7 \\
& Female & 90 & 33.3 & 33.3 & 100.0 \\
& Total & 270 & 100.0 & 100.0 & \\
\hline
\end{tabular}

Table: 2

\section{Qualification}

\begin{tabular}{llrrrr}
\hline & & & \multicolumn{2}{c}{ Valid } & Cumulative \\
& & Frequency & Percent & \multicolumn{1}{c}{ Percent } & Percent \\
\hline Valid & PhD or higher & 73 & 27.0 & 27.0 & 27.0 \\
& Master/MS/M.Phil & 160 & 59.3 & 59.3 & 86.3 \\
Bachelors & 31 & 11.5 & 11.5 & 97.8 \\
Intermediate or & 6 & 2.2 & 2.2 & 100.0 \\
below & 270 & 100.0 & 100.0 & \\
Total & & & & \\
\hline
\end{tabular}

Table: 3

BPS

\begin{tabular}{lrrrrr}
\hline & & & \multicolumn{2}{c}{ Valid } & Cumulative \\
Frequency & Percent & Percent & \multicolumn{1}{c}{ Percent } \\
\hline Valid & $11-15$ & 41 & 15.2 & 15.2 & 15.2 \\
& $16-17$ & 96 & 35.6 & 35.6 & 50.7 \\
& $18-19$ & 119 & 44.1 & 44.1 & 94.8 \\
$20-21$ & 14 & 5.2 & 5.2 & 100.0 \\
Total & 270 & 100.0 & 100.0 & \\
\hline
\end{tabular}

\section{Reliability of the constructs}

The questionnaire which is used in the study designed by Donald A Buckingham (2004) and KavithaVenugobal (2017). Once the analysis of the questionnaire completed, as per analysis of cronbach's alpha the Job stress is $0.94 \%$ Work overload $0.93 \%$, Role conflict $0.92 \%$, Work life balance $0.95 \%$ and Employee turnover intentions is $0.96 \%$ as given under the table 
Table: 4

\begin{tabular}{ll} 
& Cronbach's Alpha \\
\hline Job Stress & 0.94 \\
Work Overload & 0.93 \\
Role Conflict & 0.92 \\
Work Life Balance & 0.95 \\
Employee Turnover & 0.96 \\
Intentions & \\
\hline
\end{tabular}

\section{Correlation Analysis}

Coetzee (2003) noted that there is strong scale of correlation showed the strong linear linkbetween the variables. To check the correlation coefficient Pearson's correlation coefficient has been usedfor the correlation between the work overload, role conflict, work life balance, job stress and employee's turnover intention variables.

The given table indicates that the inter-correlations of the work overload, role conflict, work life balance, job stress and turnover intentions. As per the table there is positive, buta weak relation between work overload and employee turnover intentions having $(\mathrm{r}=$ $0.64)$ and the significance level $(\mathrm{p}<0.01)$. The $\mathrm{p}$ value indicates that relation ofwork overload and employee turnover intentions was significant.

Work overload has positive but weak relation with job stress having Pearson's coefficient $(r=0.86)$ and significance level $(\mathrm{p}<0.01)$. In that case the value of pspecifies that the relation between work overload and role conflict was significant.

Work overload has negative, but weak relation with work life balance and having Pearson's coefficient $(r=-0.648)$ and significance level $(\mathrm{p}<0.01)$. The value of $\mathrm{p}$ specifies that the relation between work overload and work life balance was significant. Work overload has positive but weak relationto role conflict having Pearson's coefficient $(r=0.77)$ and the significance level $(\mathrm{p}<0.01)$. In that case $\mathrm{p}$ value specifies that the relation between work overload and role conflict was significant.

Role conflict and turnover intention have weak affiliation, but they are positively relatedand having Pearson's coefficient $(r=0.67)$ and significance level $(p<0.01)$. As the $\mathrm{p}$ value shows that there was a significant relation between role conflict and employee turnover intentions.

The relationship of role conflict with job stress is weak, yet they are positively related as per Pearson's coefficient $(\mathrm{r}=0.83)$ and significance level $(\mathrm{p}<0.01)$. The $\mathrm{P}$ value specifies that role conflict and job stress was significant. As per Pearson's coefficient $(\mathrm{r}=$ $-0.67)$ and significance level $(\mathrm{p}<0.01)$ which show that there is a negative and a weak relationship of role conflict with work life balance yet it is significant.

As per Pearson's coefficient $(r=-0.62)$ and the significance level $(\mathrm{p}<0.01)$ there is a negative and a weak relation between work life balance and employee turnover intentions. As per $\mathrm{P}$ valuethe work life balance and employee turnoverintentions, they were significantly related to each other. 
Work life balance has negative and a weak link with job stress having Pearson's coefficient $(\mathrm{r}=-0.83)$ and significance level $(\mathrm{p}<0.01)$. In that case $\mathrm{p}$ value specifies between work life balance and job stress was significant.

The Pearson's coefficient $(r=-0.62)$ and the significance level $(\mathrm{p}<0.01)$ shows that there is a weak and negative relationship between work life balance and employee turnover intentions. Now the $\mathrm{p}$ value shows that work life balance and employee turnover intentions relate significantly to each other.

Job stress and employee turnover intentions were having a weak relationship with a positively related as the Pearson's coefficient $(r=0.66)$ and the significance level $(\mathrm{p}<$ 0.01 ) shows. As per $\mathrm{P}$ value the relationship is significant of job stress and employee turnover intentions.

Table: 5

\begin{tabular}{llllll}
\hline & $\begin{array}{l}\text { Work } \\
\text { overload }\end{array}$ & $\begin{array}{l}\text { Role } \\
\text { conflict }\end{array}$ & $\begin{array}{l}\text { Work Life } \\
\text { Balance }\end{array}$ & Job Stress & $\begin{array}{l}\text { Employee } \\
\text { Turnover } \\
\text { Intention }\end{array}$ \\
\hline $\begin{array}{l}\text { Work } \\
\text { overload }\end{array}$ & 0.93 & & & & \\
$\begin{array}{l}\text { Role conflict } \\
\text { Work Life }\end{array}$ & 0.77 & -0.648 & -0.67 & -0.95 & \\
$\begin{array}{l}\text { Balance } \\
\text { Job stress }\end{array}$ & 0.86 & 0.83 & -0.83 & 0.94 & \\
$\begin{array}{l}\text { Employee } \\
\text { turnover } \\
\text { intention }\end{array}$ & 0.64 & 0.67 & -0.62 & 0.66 & 0.96 \\
\hline
\end{tabular}

\section{Regression Analysis}

\section{Hypothesis 1: Work Life Balance and Job Stress}

$\mathrm{R}^{2}$ is indication of Work Life Balance in Job Stress that how much change will occur. The value of $\mathrm{R}^{2}$ is $-0.89 \%$ that means a change in job stress occurs due to a one-unit change in work life balance and that change can be measured by beta $(\beta)$ value. As per table, the beta value is 0.94. Positive or negative indicated signs can inspect the relationship of variables. Here, the sign is negative, which indicates that there is a negative relation between work life balance and job stress. T value defines the hypothesis status of acceptance and rejection. Here the $t$ value is 48.0 and its significant level is (0.00) which leads that the hypothesis is accepted despite the work life balance has negatively associated with job stress. 
Table: 6

\begin{tabular}{lllll}
\multicolumn{5}{c}{ Regression } \\
\hline & $\mathrm{R}^{2}$ & $\mathrm{~B}$ & $\mathrm{~T}$ & $\mathrm{Sig}$ \\
\hline Work overload & 0.42 & 0.64 & 13.93 & 0.00 \\
Role conflict & 0.45 & .067 & 14.84 & 0.00 \\
Work Life & -0.89 & 0.94 & 48.0 & 0.00 \\
Balance & & & & \\
\hline
\end{tabular}

\section{Hypothesis 2: Role conflict and Job Stress}

$\mathrm{R}^{2}$ is the indication of Role Conflict in Job Stress that how many changescan occur. The value of $\mathrm{R}^{2}$ is $0.45 \%$ that means a change in job stress occurs due to a one-unit change in role conflict and that change can be measured by beta $(\beta)$ value. As per table the beta value is 0.67. Positive or negative indicated signs can inspect the relationship of variables. Here, the sign is positive which indicates that there is a positive relation between role conflict and job stress. T value defines the hypothesis status of acceptance and rejection. Here the $t$ value is 14.84 and its significant level is $(0.00)$ which leads that the hypothesis is accepted and the role conflict has positively associated with job stress.

Table: 7

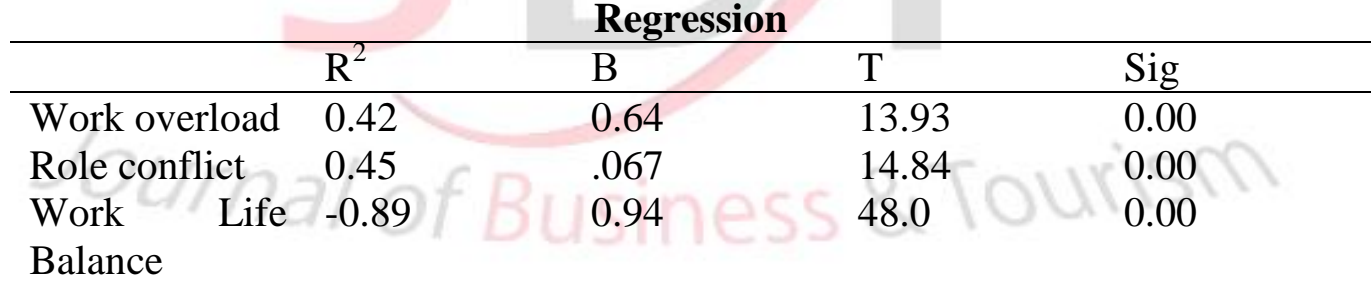

\section{Hypothesis 3: Work overload and Job Stress}

$\mathrm{R}^{2}$ is indication of Work Overload in Job Stress that how much change can be occur. The value of $R^{2}$ is $0.42 \%$ that means a change in job stress occurs due to a one unit change in work overload and that change can be measured by beta $(\beta)$ value. As per table the beta value is 0.64 . The relationship of variables can be inspected by positive or negative indicated signs. Here, the sign is positive which indicates that work overload and job stress has a positive relationship. T value defines the hypothesis status of acceptance and rejection. Here the t value is 13.93 and its significant level is $(0.00)$ which leads that the hypothesis is accepted and the work overload has positively associated with job stress.

Table: 8

\section{Regression}

$\begin{array}{llll}\mathrm{R}^{2} & \mathrm{~B} & \mathrm{~T} & \mathrm{Sig}\end{array}$




\begin{tabular}{lllll}
\hline Work overload & 0.42 & 0.64 & 13.93 & 0.00 \\
Role conflict & 0.45 & .067 & 14.84 & 0.00 \\
Work Life & -0.89 & 0.94 & 48.0 & 0.00 \\
Balance & & & & \\
\hline
\end{tabular}

\section{Mediation Analysis}

\section{Meditating effect of job stress between work overload and employee turnover intention.}

To test the mediator Preacher and Hayes (2004) has suggested to use bootstrapping for resampling the same test has been used to find the mediating of job stress between work overload and employee turnover intention. The comparison of testing mediating between Barron and Kenny (1986) and (Preacher \& Hayes, 2004) the nonparametric approach of (Preacher \& Hayes, 2004) approach is superior.

While using the sample of 270 ,we bootstrapped the results we received with the confidence level (CI) of $95 \%$. The mediation is determined when in indirect effect there at no zero included (Preacher \& Hayes, 2004). The mediation table is given as under.

Table: 9

Mediation Analysis

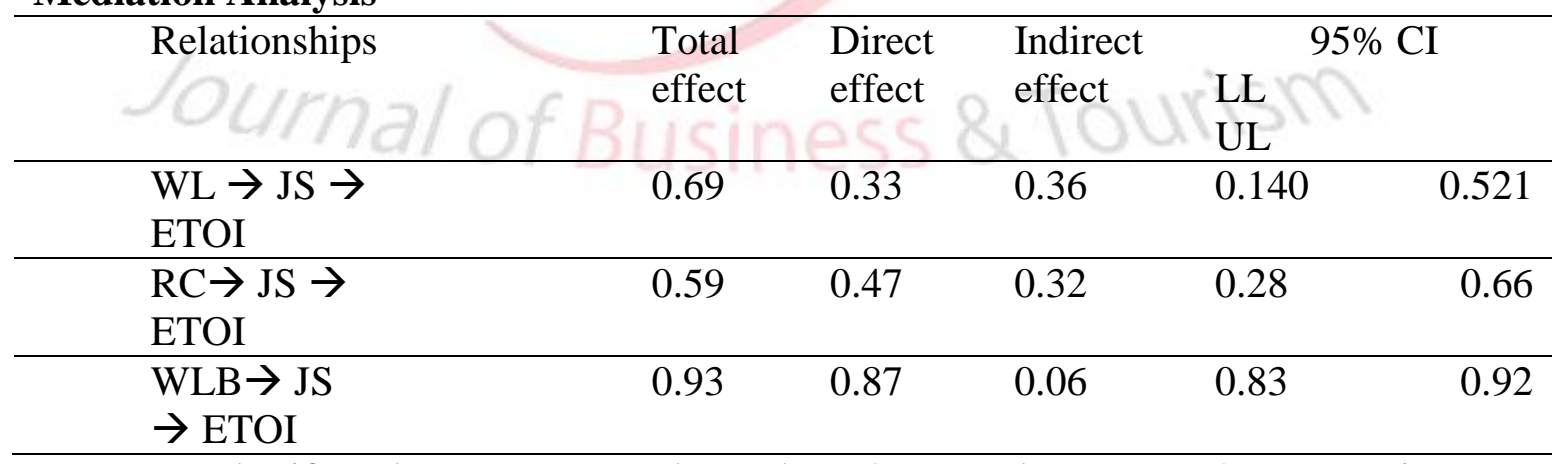

$\mathrm{WLB}=$ Work Life Balance, WL $=$ Work Load, ETOI= Employee Turn Over Intention, $\mathrm{JS}=$ Job Stress, $\mathrm{RC}=$ Role Conflict

As shown in table9, there is a significant direct effect $(0.33)$ of workload on employee turnover intention. Similarly, the indirect effect between work as the total effect $(0.69, \mathrm{p}$ $<.01)$ and by job stress the indirect effect $(0.36, \mathrm{p}<.01,95 \% \mathrm{CI}=0.140,0.521)$ was significant. The (direct and indirect) total effect of work overload on employee turnover intention 0.69. The direct and indirect effect of work overload on employee turnover is the result because of unmediated and mediated which means when the standard deviation rise from 1 in work overload so the standard deviation of employee turnover intention 
rise by 0.69 . Hence the results of $\mathrm{H} 4$ of the study has believed to be approved for the role of mediation of job stress between work overload and employee turnover intention.

Similarly, Table9 shows that direct effect has significant (0.47) of Role Conflict on employee turnover intention as the total effect $(0.59, \mathrm{p}<.01)$ and by job stress the indirect effect $(0.32, \mathrm{p}<.01,95 \% \mathrm{CI}=0.28,0.66)$ was significant. The (direct and indirect) total effect of role conflict on employee turnover intention 0.59 . The direct and indirect effect of role conflict on employee turnover is the result because of unmediated and mediated which means when the standard deviation rise from 1 in role conflict so the standard deviation of employee turnover intention rise by 0.59 . Hence the results of $\mathrm{H} 4$ of the study has believed to be approved for the role of mediation of job stress between role conflict and employee turnover intention.

As the table 9 shown that direct effect has significant (0.87) of work life balance on employee turnover intention as the total effect $(0.93, \mathrm{p}<.01)$ and by job stress the indirect effect $(0.06, \mathrm{p}<.01,95 \% \mathrm{CI}=0.83,0.92)$ was significant. The (direct and indirect) total effect of work life balance on employee turnover intention 0.93 . The direct and indirect effect of work life balance on employee turnover is the result because of unmediated and mediated which means when the standard deviation rise from 1 in work life balance so the standard deviation of employee turnover intention rise by 0.93 . Hence the results of $\mathrm{H} 4$ of the study has believed to be approved for the role of mediation of job stress between work life balance and employee turnover intention.

\section{Conclusions}

The current study has highlighted results for the theorists and practitioners as it examined the mechanism of their thoughts regarding why the job stress are high and which leads to employee turnover intentions.For the purpose of this research, we selected respondents from Abdul Wali Khan University Mardan to determine the impact of the mediating role of job stress in the relationship between determinants of work life balance, role conflict and work overload on employee turnover intention. The research shows that the work life balance has negatively related to job stress, whereas role conflict and work overload is positively related to job stress. As the job stress is performing a mediating role in the research between work life balance, role conflict, work overload and employee turnover intention, therefore the relation between job stress and employee turnover intention is also examined. The result shows positive relation between these two which means that the increase in the job stress will make the level of employee turnover intention upward and vice versa. The current study has many useful results. Like, the result discloses that role conflict, work life balance and work overload that creates stress among the employees which leads them to think for turnover intention.

The current paper tried to cover employee's performance by providing few questions. 
(a) The work station demands of extra work, which in return affects work life balance and build work overload which leads to job stress.

(b) The workers startplaying as the mediator roleof job stress and it takes the employee to change their behaviouror start thinking for turnover intention.

(c) Does stressful job effects the behaviour.

The result shows that work life balance has negative associations with job stress while role conflict and work overload has positively related. Job stress fully mediates his relationship with all rest of three independent variables. This finding demonstrates that job stress positively affects employee turnover intentions.If the employee feels like the current job has given him stress on a daily basis his intentions may lead to quit his current job.

The results have suggested the organization to think about their employee behaviour and enhance to improve their strategic objectives.

\section{References}

Ahmed, M., \& Nawaz, N. (2015). Impact of organizational commitment on employee turnover: $\quad$ A case study of Pakistan International Airlines (PIA). Industrial Engineering Letters Journal, 5(8).

Armour, S. (2002, June 6). Workers put family first despite slow economy, jobless fears. USA

Today, p. 3B.

Baron, Reuben M.,Kenny, David A. The moderator-mediator variable distinction in social psychological research: Conceptual, strategic, and statistical considerations. Journal of Personality and Social Psychology, Vol 51(6), Dec 1986, 1173-1182.

Blaug, R. (2007). Stress at Work: A report prepared for The Work Foundation's Principal Partners.

Bliese, P. D., \& Castro, C. A. (2000). Role clarity, work overload, and organizational support: Multilevel evidence of the importance of support. Work and Stress, 14(1), 65-73.

Britt, T.W. and Dawson, C.R. (2005), "Predicting work-family conflict from workload, job attitudes, group attributes, and health: a longitudinal study", Military Psychology, 17, 203-27.

Buckingham, D. A. (2004). associations among stress, work overload, role conflict, and self-efficacy in maine principals. Maine.

Chen, MF, Lin, CP \& Lien, GY 2011, 'Modeling job stress as a mediating role in predicting turnover intention', The Service Industries Journal, vol. 31, no. 8, pp. 1327-1345.

Chiang, F. F. T., Birtch, T. A., \& Kwan, H. K. (2010). The moderating roles of job control and work life balance practices on employee stress in the hotel and 
catering industry. InternationalJournal of Hospitality Management, 29, 2532.

Claessens, B.J.C., Eerde, W.V., Rutte, C.G. \& Roe, R.A. (2004). Planning behavior and perceived control of time at work. Journal of Organizational Behavior, 25, 93750.

Coetzeeis Disgrace. Research in African Literatures 34(2), 155-162.

Duxbury L, Higgins C. Work life in the new millennium: where are we? Where do we need to go? Discussion Paper, Canadian Policy Res Networks; 2001. October. 12.

Firth, L., Mellor, D. J., Moore, K. A., \&Loquet, C. (2004). How can managers reduce employee intention to quit? Journal of managerial psychology, 19(2), 170187.

Frone, M. R. (2003). Work-family balance. In J. C. Quick \& L. E. Tetrick (Eds.), Handbook of occupational health psychology (pp. 143-162). Washington, DC: American Psychological Association.

Greenhaus, J. H., \& Powell, G. N. (2006). When work and family are allies: A theory of work family enrichment. Academy of Management Review, 31, 72-92.

Hans SelyeScience New Series, Vol. 122, No. 3171 (Oct. 7, 1955), pp. 625-631

Hon, A. H., Chan, W. W., \& Lu, L. (2013). Overcoming work-related stress and promoting employee creativity in hotel industry: The role of task feedback from supervisor. International Journal of Hospitality Management, 33(1), 416-424.

House, R. J., Schuler, R. S., \&Levanoni, E. (1983). Short notes: Role conflict and ambiguity scales: Reality or artifacts? Journal of Applied Psychology, 68, 334-337

Jackson, S. E., \& Schuler, R. S. (1985). A meta-analysis and conceptual critique of research on role ambiguity and role conflict in work settings. Organizational behavior and human decision processes, 36(1), 16-78.

Jawahar, I. M., Stone, T. H., \&Kisamore, J. L. (2007). Role conflict and burnout: The direct and moderating effects of political skill and perceived organizational support on burnout dimensions. International Journal of Stress Management, 14(2), 142.

Jones, M. L. (1993). Role Conflict: Cause of Burnout or Energizer? Social Work, 38, 2.

Karatepe, O. M. (2008). Work-family conflict and facilitation: Implications for hospitality researchers. In Handbook of hospitality human resources management (pp. 237-264). Oxford: Butterworth, Heinemann, Elsevier.

Kahn, R., Wolfe, D., Quinn, R., Snoek, J., \&Rosentbal, R. (1964). Organizational stress: Studies in role conflict and ambiguity. New York:Wiley.

Karatepe, O. M. (2010). The effect of positive and negative work-family interaction on exhaustion: Does work social support make a difference? International Journal of Contemporary Hospitality Management, 22, 836-856. 
Karatepe, O. M., \&Aleshinloye, K. D. (2009). Emotional dissonance and emotional exhaustion among hotel employees in Nigeria. International Journal of Hospitality Management, 28, 349-358.

Karatepe, O. M., \&Baddar, L. (2006). An empirical study of the selected consequences of frontline employees' work-family conflict and family-work conflict. Tourism Management,27, 1017-1028.

Karatepe, O. M., \&Sokmen, A. (2006). The effects of work role and family role variables on psychological and behavioral outcomes of frontline employees. Tourism Management, $\quad$ 27, 255-268.

Kinman, G. (2014). Doing More with Less? Work and Wellbeing in Academics. Somatechnics, 4, 219-235.

Kovach, K. A. (1987). What motivates employees? Workers and supervisors give different answers. Business Horizons, 30. 58-65.

Long, C. S., \&Thean, L. Y. (2011) Relationship between Leadership styles, Job Satisfaction and Employees' Turnover Intention: A literature Reveiw. Research Journal of Business

Long, C.S., Azami, A., Kowang, T.O., \&Fei, G.O. (2016). An analysis on the relationship between work family conflict and turnover intention: A case study in a manufacturing company in Malaysia. International Business Management, 10(3), 176-182.

Mbah, S.E., \&Ikemefuna, C.O. (2012). Job satisfaction and employees' turnover intentions in total Nigeria plc.in Lagos State. International Journal of Humanities and Social Science, 2(14), 275-287.

Mansour, S. (2012). L'influence des conditions de travail sur le stress professionnel du personnel en contact avec la clientele: Le cas du secteur hotelier en Syrie[The effects of working conditionson occupational stress of personal in contact with customers: The case of the hotel sectorin Syria]. Nancy: XXIIIèmeCongrès de l'AGRH.

Namasivayam, K., \& Mount, D. (2004). The relationship of work-family conflicts and family- $\quad$ work conflict to job satisfaction. Journal of Hospitality and Tourism Research, 28, 242- 250.

Namasivayam, K., \& Zhao, X. (2007). An investigation of the moderating effects of organizational commitment on the relationships between work-family conflict and job satisfaction among hospitality employees in India. Tourism Management, 28, 1212-1223.

Nyamubarwa, W. (2013). I am considering leaving soon-Turnover intentions of academic librarians in Zimbabwe. Journal of Business Administration and Education, 4(1), 76-90.

Oluwafemi, O.J. (2013). Predictors of turnover intention among employees in Nigeria's oil industry. Organisations and Markets in Emerging Economies, 4(2), 42-63. 
Preacher \& Hayes, (2004). Behavior Research Methods, Instruments, \& ComputersNovember 2004, Volume 36, Issue 4, pp 717-731.

Phetkaew, C. (2015). Influence of leadership behaviour, organisational culture and organisational commitment on employee turnover intention. Thesis Submitted to School of Business Management University Utara Malaysia, in Fulfilment of the Requirement for the Degree of Doctor of Philosophy.

Rizzo, J. R., House, R. J., \&Lirtzman, S. I. (1970). Role conflict and ambiguity in complex Organizations. Administrative Science Quarterly, 15(2), 150-163.

Salami, S. O. (2011). Job stress and burnout among lecturers: Personality and social support as moderators. Asian Social Science, 7(5), 110-121.

Sheraz, A., Wajid, M., Sajid, M., Qureshi, W. H., \&Ramzan, M. (2014). Antecedents of job stress and its impact on employee's job satisfaction and turnover intentions. International Journal of Learning \& Development, 4(2), 204226.

Singh, J. (1998). Striking a balance in boundary-spanning positions: An investigation of some unconventional influences of role stressors and job characteristics on outcomes of salespeople', Journal of Marketing, vol. 62, no. 3, pp. 69-86.

Statistical Bulletin (2013). Annual Survey of Hours and Earnings, 2013 Provisional Results.

Tinker, S., \& Moore, K. A. (2001, November). The impact of long work hours on the family- work relationship and health. In Inaugural Conference of Australian Psychological Society Relationships Interest Group, Melbourne (pp. 17-18).

Tuzun, E. \& Dalmau, J. (2007) Limbic Encephalitis and Variants: Classification, Diagnosis and Treatment. Neurologist, 13, 261-271.

Tubre, T. C., \& Collins, J. M. (2000). Jackson and Schuler (1985) revisited: A metaanalysis of the relationships between role ambiguity, role conflict, and job performance. Journal of management, 26(1), 155-169.

Yavas, U., Babakus, E., \&Karatepe, O. M. (2008). Attitudinal and behavioral consequences of work-family conflict and family-work conflict International Journal of Service Industry Management, 19, 7-31. 